Research Article

\title{
Competition Order and Innovation Behaviors of Enterprise in China
}

\author{
Weijun Cui $\mathbb{D}^{1}{ }^{1}$ Guang Chen, ${ }^{2}$ and $\mathrm{Yu} \mathrm{Fu}^{1}$ \\ ${ }^{1}$ School of Business, Nanjing University of Information Science \& Technology, Nanjing 210044, China \\ ${ }^{2}$ Bureau of Academic Divisions, Chinese Academy of Sciences, Beijing 100190, China \\ Correspondence should be addressed to Weijun Cui; 000928@nuist.edu.cn
}

Received 30 January 2020; Accepted 26 March 2020; Published 1 May 2020

Guest Editor: Lifei Chen

Copyright (c) 2020 Weijun Cui et al. This is an open access article distributed under the Creative Commons Attribution License, which permits unrestricted use, distribution, and reproduction in any medium, provided the original work is properly cited.

This study addresses the apparent puzzle that China made great progress in mobile phone manufacturing despite weak intellectual property protection. Using the China 2012 Enterprise Surveys Data set of World Bank enterprises survey, we investigated whether competition order mattered for innovation behaviors of enterprise and mainly drew three major conclusions. First, when there are unregistered or informal competitors in the market, enterprises tend to choose innovation to improve the current situation of their own operations, and they may increase the R\&D investment. Second, when the unregistered or informal competitors in the market become obstacles to the enterprise, with the rise of disorderly barriers to competition, enterprises will reduce their decision-making of innovation behavior or the intensity of R\&D investment. Third, the impartiality degree of court may have a moderating effect on the relationship between competition order and corporate innovation behavior.

\section{Introduction}

Innovation is the motivation of sustained economic growth $[1,2]$ and is a prerequisite for business survival [3]. As an important subject of innovation activities, enterprises play an irreplaceable role in the process of transforming innovation theory and ideas into productive forces, not only with high efficiency and low cost but also with various innovation points [4]. Through the promotion of enterprise products, production technology or management methods change to improve the production efficiency of enterprises $[5,6]$, innovation can promote the development of emerging industries and technological upgrading, promote the continuous improvement of the industrial chain, drive the development of related industries $[7,8]$, so as to maintain sustainable economic growth [9].

The organization is surrounded by the environment and maintained by external energy input [10]. New ideas emerge from both inside and outside of the organization and may eventually form innovation [11]. As a common organizational form, enterprises exist in a specific environment all the time, and their decision-making and business activities will be affected by the external environment [12-14]. The external environment of the enterprise includes market environment $[15,16]$, social environment [17], policy environment [18-20] and enterprise culture environment [21]. In addition, market capacity, market competition, and other factors also play an important role in the selection of innovative projects [22, 23]. Government regulation of industries have a significant impact on innovation activities [20], especially in developing countries like China. A large number of scholars have paid attention to the relationship between competition and enterprise innovation from both theoretical and empirical aspects and have drawn different conclusions. Most of the studies have examined the impact of the intensity of market competition on innovation, but few have paid attention to the impact of market competition order on enterprise innovation behavior.

Opportunistic, unfair, and even illegal market competition is common in China, when the legal framework for the definition and protection of property rights is inadequate in transition economies [24-26]. Innovation itself has high risk 
and uncertainty [27]. Coupled with the abovementioned situation, innovation has become a high-risk and low-income strategy. Therefore, the legal system for the maintenance of the competition order has become an important part of reducing the cost of innovation and protecting innovation results. Credibility can be an important asset of a government. The operation of the legal system depends on the credibility of the court [28]. The enterprises' evaluations of the impartiality of the court may affect their view on the market competition order, thus affecting their innovation behaviors. Few scholars have paid attention to this possible regulatory role alone.

Will enterprises have a tendency to choose innovation when the market competition order is good? Also, if the enterprise thinks that the judicial environment is fair, will its decision-making and $\mathrm{R} \& \mathrm{D}$ investment intensity on innovation behavior be enhanced? These two questions are the key issues that this paper wants to discuss intensively. In addition, through this study, we make valuable contributions to the literature from two aspects. Firstly, we develop theoretical insights into the competition order, and the fact shows that it does not necessarily influence the enterprise innovation behaviors negatively. Secondly, we have fully explained how the Chinese market has achieved rapid innovation and development since 1978 when intellectual property protection is weak and the level of competitors is uneven.

The rest of the paper is organized as follows: Section 2 reviews the relevant literature on the impact of external environment, such as competition and judicial environment, on enterprise innovation and introduces the different hypotheses tested in the empirical section. Section 3 describes the data, variables and models used in this paper. Section 4 reports the empirical analysis of the data. Using the World Bank's Enterprise Survey data, we test whether the formal enterprises would reduce their innovation behaviors or R \& $\mathrm{D}$ investment when the competition order is destroyed by informal enterprises and discuss the moderating function of the degree of the impartiality of court. The results do not totally prove our hypotheses. Finally, Section 5 presents some concluding comments and the deficiency of the research.

\section{Theory and Hypotheses}

2.1. The Influence of Competition Order on Innovation Behavior. Research on the influence of competition on enterprise innovation has a long history, and a large number of scholars and literature have proved that there is a huge correlation between competition and enterprise innovation. The research results are mainly divided into three types: positive, negative, and reverse " $U$ " type. The earliest positive impact research is given by Schumpeter, and he believes that competition has a positive impact on innovation, and large enterprises are more innovative than small enterprises [2]. The "competition" here refers to the degree of concentration of the market, and it also can represent the intensity of competition. Then arrow uses the economic model to deduce that competition can make the incentive intensity of innovation stronger, and if the enterprise is in a monopoly position, the incentive of innovation is likely to be weakened [29]; Connolly and Hirschey believe that the higher the product market concentration is, the more the $\mathrm{R} \& \mathrm{D}$ investment enterprises will put in [30]. Porter also argues that competition will force enterprises to innovate to change the market situation [31]. Bai et al. used 1995-2002 China's large and medium-sized industrial enterprises data [32]. Their empirical results show that market competition can significantly affect the efficiency of enterprise innovation activities, and the competitive industry leading-edge technology will progress faster. Using the 1999-2007 survey data of China's industrial enterprises, Zhang et al. proved that, in China, improving competition can promote enterprise innovation and research and development activities [33]. He and others did some researches on nonfinancial A-share listed companies in Shenzhen and Shanghai from 2007 to 2012 [34]. The results show that product market competition has a positive effect on $R \& D$ intensity of enterprises, but the impact on state-owned enterprises is weak.

Horowitz found that competition had a negative impact on technological innovation [35]. Grossman and Helpman state that the more competitive the competition is, the more likely the innovation is to be imitated or replaced, the less the revenue it brings, and the less the willing firms are to innovate [1]. The scholars represented by Aghion think that the influence of competition on innovation is inverted " $U$ " type. He constructs a dynamic competition model of manufacturers and gives a theoretical model of inverted " $U$ " type between product competition and market innovation $[36,37]$. In the past two years, there have been more studies on the inverted " $U$ ". Fan et al. use the unbalanced panel data of 28 double-digit industries in China's manufacturing industry from 2000 to 2006 [38]. Li and others take the manufacturing enterprises of listed companies in China from 2007 to 2012 as samples [39]. Also, Xu uses the data of 2384 enterprises in Shanghai and Shenzhen A-share listed companies from 2009 to 2014 [40].

Different samples and variables, different macroenvironments, and different focuses of the study result in the different results. However, whether it is positive, negative, or inverted " $U$ " type of the relationship between competition and innovation, all these studies can show that competition has an important and significant impact on enterprise innovation. In addition, through the review of the literature, we found that most of the research studies are concerned with the enterprise market competition intensity. Few scholars have considered that the enterprise market competition in essence has a competition order. We found a definition called "dysfunctional competition" which means "the competitive behavior of firms in a market that is perceived as opportunistic, unfair, or even unlawful" [41]. Due to the dysfunctional competition, start-ups have to focus on their resource shortage through innovation strategy $[42,43]$. Like the dysfunctional competition, disorderly competition order enterprises faced may affect the innovation behavior of enterprises. When the informal competitors occur, some similar products that do not meet industry access standards will enter the market at a lower 
cost due to the lack of legal supervision. Informal competitors force companies to focus on finding more effective innovation strategies [25]. The phenomenon mentioned above will make the market competition order be disordered. The products and services of the enterprise are easy to be imitated and copied, and the profits brought by the enterprise innovation will be greatly compressed. Also, under the influence of historical and cultural factors in China, most enterprises are nonrisk preferences, so they will try to avoid engaging in risky R \& D projects [44]. Disorderly competition order makes this high-risk innovation risk higher, and enterprises are more reluctant to choose innovation. They may also reduce the intensity of the original innovation investment. So, we give the following assumptions:

Hypothesis 1a: the better the competition order is, the more innovative the enterprise is

Hypothesis $1 b$ : the better the competition order is, the greater the innovation investment intensity is.

\subsection{The Moderating Effect of Impartiality Degree of} Court on the Relationship between Competition Order and Innovation Behavior. In China, judicial justice means that, in the process of dealing with all kinds of cases, the state judicial organs not only can use entity norms to reflect the principle of fairness to confirm and distribute specific rights and obligations but also can make the confirmation and distribution process and way to reflect the fairness [45]. Its value lies in maintaining social justice, building social order, and ensuring social security [46]. Countries have developed mechanisms, such as patent protection systems, to encourage, protect, and reward enterprise innovation. Some studies have shown that the level of intellectual property protection provided by these mechanisms to the enterprises positively affects the innovation strategies and $\mathrm{R} \& \mathrm{D}$ investment [47-50]. In The National Innovation Enterprise Survey Yearbook- $2017^{1}$, 48.5\% of entrepreneurs think "policies related to the creation and protection of intellectual property rights" are effective, and only $24 \%$ of entrepreneurs think it is ineffective. Using the policy system to protect innovation results will improve unfair competition or patent infringement. The market competition environment will be more fair and reasonable [51] and tend to be orderly. Also, a good policy environment helps to reduce the cost of enterprises to protect their innovation results. It also can enhance entrepreneurs' confidence in innovation investment. Judicial justice can guarantee the protection of innovation achievements through the policy system.

On the one hand, the more stringent the policy environment, the higher the external "mandatory" enterprises face. The enterprise is more inclined to risk aversion behavior, and it may show more compliance with the order in the competition. On the other hand, if enterprises agree with their own judicial environment and believe that justice is fair, then they will be more willing to believe that the market competition order is maintained, and their own development can be protected. Once disorderly competitors appear in the market, companies are willing to and can immediately improve the passive situation through innovation, and then judicial justice may strengthen the relationship between competition order and innovation behavior. So, we make the following assumptions:

Hypothesis 2a: the higher the impartiality degree of court is, the greater the impact of competition order on the choice of innovation behavior of enterprises is.

Hypothesis 2b: the higher the impartiality degree of court is, the greater the impact of competition order on the innovation investment intensity of enterprises is.

\section{Data and Variables}

3.1. Data and Samples. Our data are mainly from the China 2012 Enterprise Surveys Data set of World Bank enterprise survey $^{2}$. The data includes data on 2,700 private and 148 state-owned enterprises in China for a full fiscal year from December 2011 to February 2013, as well as some data for 2009. The private enterprises here are defined according to the notes of the World Bank on the survey; in fact, some of them have a large proportion of state-owned shares (according to the question $\mathrm{B}^{3}{ }^{3}$ ). However, it cannot be determined whether it meets the standards of state-owned enterprises as determined in the " 32 orders" jointly issued by the State-Owned Assets Supervision and Administration Commission and China's Ministry of Finance. Therefore, when we use the data in the following, we still refer to this part of the enterprises as private enterprises.

We screened the data in the following logic order. First, we deleted 148 state-owned enterprises. These 148 stateowned enterprises involved in the survey are $100 \%$ owned by the state. In the survey, the manufacturing industries in which these enterprises are located are not classified and cannot be combined with the data of 2,700 private enterprises. Therefore, the data of 148 state-owned enterprises are excluded, and only the data of 2700 private enterprises are selected. Then, according to the questionnaire survey of question $\mathrm{A}^{4}$, we removed the data of nonmanufacturing enterprises. Finally, based on the questionnaire survey of $A 7^{5}$, we removed the subsidiary company data. A total of 1515 enterprises were selected, which involved 19 industries $^{6}$ such as food manufacturing and textile manufacturing.

3.2. Variables and Models. In order to test the relationship between the competition order and the innovation behavior of enterprises and the influence of impartiality degree of court on the abovementioned relationship, we have established the following model to carry out data regression.

In order to prevent heteroscedasticity from affecting the results, we cluster standard errors in the industry quartile codes of the main products of the enterprises (according to question d1a2) in all regressions mentioned below. The reason why we did not use clustering at the level of binary codes of provinces, cities, and industries is that when the number of clusters is lower than 42, using the method of cluster standard deviation to solve the heteroscedasticity problem in the regression model will produce errors [52]. In 
our data, the binary codes of provinces, cities, and industries are 12 and 19, respectively, which are all less than the minimum cluster number of 42 .

Our dependent variable is innovation behavior. We use two indicators to measure the innovation behavior of enterprises. One indicator is called Innovation behavior decision-making (IBD), i.e., whether there is innovation in the enterprise, which is used to measure whether there is innovation behavior in the enterprise. Another indicator is called Innovation behavior $R$ \& D investment intensity (IBR), i.e., the investment in research and development of the enterprise is small, which is used to measure how much innovation behavior R \& D intensity the enterprise has. We consider that if the enterprise has introduced new products or services in the past three years, the enterprise currently has innovation behavior, and if not introduced, there is no innovation behavior. R \& D investment intensity is measured by the proportion of the average annual R \& D investment of the surveyed enterprises in the past three years to the average annual sales revenue of the last three years, and the average annual sales revenue of the last three years is estimated by the sales revenue of 2011 and 2009.

Our key explanatory variable is competition order. We observe the research on unfair competition and illegal competition in the existing literature. The indicators used mainly include (1) the number of illegal competition activities in the industry, including illegal reproduction of new products, fake products, and trademarks; (2) the number of times that market competition laws and regulations failed to protect the company's intellectual property rights; and (3) increase in unfair competition among other enterprises in the industry $[25,53]$. With reference to these common indicators and in combination with the questions in the questionnaire, we choose the quality of "Whether the competitive environment of enterprises is orderly (C)" and "Degree of obstacles caused by disorder of competitive environment of enterprises (CO)" as agents to measure the competition order. These two indicators can reflect the illegal phenomenon in the market where the enterprise is located. The corresponding question to "Whether the competition environment is orderly (C)" in the questionnaire is "Does the enterprise compete with unregistered or informal enterprises?". The answer options are "yes" and "no", and we replaced them when setting variables. If the answer option is "yes", it means bad competition order, assigning it to 0 , and the answer option is "no" meaning good competition order, assigning it to 1 . The corresponding question to "Degree of obstacles caused by disorder of competitive environment of enterprises (CO)" is "To what extent does the behavior of the informal competitors create obstacles to the existing operations of the enterprise?". The options answered are discrete variables of 0,1 , 2, 3, and 4, which represent five different obstacle levels from low to high. When analyzing the data, we found that 95.91\% of the answers given by enterprises were concentrated on the three levels of 0,1 , and 2 , which caused the data distribution to be skewed. So, we add 1 to all the data and take logarithm to reduce the impact of uneven distribution.
Impartiality degree of court (CF) is our moderating variable. We use the subjective evaluation of the surveyed enterprises on whether the court is fair or not as a measurement index. At present, there are four types of evaluation methods for impartiality degree of court in China: setting up specific systems, evaluating the quality of cases, conducting questionnaire surveys, and conducting cognitive experiments [54]. It will be more practical to investigate the public's fair feelings subjectively than using the objective standard. Studies of procedural justice suggest that judgments about the fairness of decision-making procedures are the primary antecedent of people's willingness to voluntarily accept decisions and obey rules $[55,56]$. The social psychology's perception and evaluation of the fairness of the judicial system will affect the public's response to the judicial system and procedures. Therefore, subjective feeling of enterprises is more meaningful for enterprises to choose innovation behaviors.

In the empirical analysis, we also controlled for other factors that might possibly affect innovation behavior, including top manager characteristics, international certification, enterprise characteristics, industry characteristics, and region characteristics, which were variously used in previous studies of enterprise innovation.

Top manager characteristics include Top Manager Experience (Experience) and Gender of Top Manager (Gender). A top manager's interpretation of the personality of the environment in which he or she faces affects the behavior of the organization [57]. Top managers' innovativeness makes them more likely to adopt exploration orientation over exploitation orientation in innovation [58]. International certification (Certification) can improve enterprise innovation. Terziovski and Guerrero examine the impact of ISO 9000 certification on product and process innovation performance of 220 Australian organizations [59]. It shows that ISO 9000 certification tends to drive out variance increasing activities, which in turn affects the organization's ability to innovate. Enterprise characteristics include Enterprise size (Size), Enterprise age (Age), and State-owned shares of the enterprise (SOE). Evidence derived from a large sample of Chinese manufacturing firms demonstrates that state ownership positively moderates the effect of R \& D intensity on innovation performance. However, state ownership is not equally beneficial for all firms [60]. Furthermore, we found that in the World Bank survey of private enterprises, 60 enterprises have state-owned shares, and $96.7 \%$ of the stateowned enterprises have more than $51 \%$ of the state-owned shares. This situation may have an impact on the innovation behavior of the enterprises we examined. Therefore, we also regard the state-owned shareholding as one of the variables to study the characteristics of enterprises. With regard to industry characteristics (Industry), we mainly focus on the different impacts of different technology-intensive enterprises. According to OECD technology intensity classification, we classified 19 industries involved in the survey into low, medium, and high technology intensity industries. Three industry dummy variables are set in regression to control the industry fixed effect of the enterprise. With regars to regional characteristics (region), according to the 
Yangtze river delta, Pan pearl river delta, Pan Bohai, and other economic circle four types of regional classification, we set up three regional dummy variables in the regression, to control the regional fixed effect of enterprises.

The specific variable design is shown in Table 1.

\section{Empirical Analysis}

Table 2 reports the results of descriptive statistics and correlation analysis of main variables. We found that $C$ and $C O$ were significantly correlated with $I B D$ and $I B R$, and there was no significant correlation between $C F$ and $I B D$ or $I B R$. $C$ and $C F$ were significantly correlated at the level of $10 \%$. Besides, the correlation coefficient between $C$ and $C O$ was -0.717 , and it is significant at the level of $1 \%$. Table 3 reports the values of VIF. The VIF value is an indicator used to test whether there is multicollinearity between variables. Since the dependent variable $I B D$ is a binary variable of $0-1$, we choose the Probit model in regression. For this regression method, the main observation index is not the coefficient of each variable in the regression, but their marginal effect, so there is no need to use VIF values to detect the relationship between the variable $I B D$ and other variables. At the same time, the dependent variable $I B R$ is a continuous variable distributed between 0 and 1 . We choose the OLS model in regression, so we must check the VIF values of IBR and other variables. The tolerances of all variables are less than 1 , and their VIF values are much less than 10 . Those indicate that there is no significant multicollinearity between our variables.

Table 4 reports the preliminary regression results of models. Among them, the dependent variable of model $1 \sim$ model 4 is $I B D$, and the dependent variable of model $5 \sim$ model 8 is $I B R$. Model 1 and model 5 take $C$ as independent variables. Model 2 and model 6 take $C$ and $C O$ as independent variables. Also, model 3 and model 7 add $C F, C$, and $C F$ interaction terms and the $C O$ and $C F$ interaction terms on the basis of model 2 and model 6. Considering the collinearity between the interaction item and the lower order item, we center the interaction item when setting the interaction items.

In addition, it can be seen from Table 4 that model 3 and model 4 are different analysis methods of the same variables. When we regressed model 3 and model 4 , we calculated the marginal effects of the Probit method and Logit method, respectively. The marginal effects are shown in Table 4 . We can see that the coefficients of model 3 and model 4 are basically the same in size, direction, and significance. We also calculated the accurate prediction ratios of the two models, $69.68 \%$ and $69.90 \%$, respectively, which were basically equal. Therefore, we think that the original model about $I B D$ is not sensitive to the choice of different methods, which shows that the original model is robust. Model 7 and model 8 also illustrate the robustness of the original model about $I B R$. Since we are concerned with the direction in which the core variables affect dependent variables, the potential endogeneity between variables is not addressed. We will analyze the results mainly based on the Probit method and OLS method.
By observing model 1 , we find that $C$ has a significant negative incentive to $I B D$. This shows that when there are unregistered or informal competitors in the market competition, enterprises will tend to choose innovation. Namely, hypothesis $1 a$ is falsified. For most enterprises, the products or services are easy to imitate, even plagiarism, especially when there are unregistered or informal competitors in the market. Also, this kind of imitation and plagiarism makes the production or service become easier and cheaper. For consumers, when similar products or services only have differences in price, they are more willing to choose the one with lower price. This kind of preference makes enterprises lose some consumers. In order to improve this situation, enterprises may choose to innovate to constantly improve the function of the original products or services and constantly develop new products or services to occupy the market, to reverse this sales disadvantage caused by disorderly market competition.

After we added $C O$ to model 2, the impact of $C$ on $I B D$ is still significantly negative, and $C O$ has a small positive effect on $I B D$, but this effect is not significant. After adding $\mathrm{CF}$ and the two interaction terms of $C$ and $C F$ and $C O$ and $C F$ in model 3, the impact of $C$ on $I B D$ is still negative and significant at the level of $1 \%$, indicating once again that the competition order has a significant negative effect on the decision-making of innovation behavior. At the same time, the interaction term between $C$ and $C F$ is negative, and the interaction term between $C O$ and $C F$ is significantly negative, indicating that it is impossible to fully verify whether impartiality degree of court has a regulatory effect on the relationship between competition order and innovation behavior decision-making. The marginal effect of $C O$ on $I B D$ is negative, the marginal effect of $C F$ is negative, and their interaction terms are significantly negative, indicating that the impartiality degree of court on the relationship between the competition order and innovation behavior decision-making has a moderating effect. The hypothesis $2 \mathrm{a}$ is partially verified. It also shows that when the competition order of the enterprise's market is poor, the enterprise tends to innovate, but as this poor competition order becomes their burden, the enterprise's innovation will begin to weaken. At the same time, when enterprises think that the impartiality degree of court in their market is high, this kind of innovation triggered by poor competition order will not be weakened because of the burden on enterprises. Enterprises will continue to strengthen innovation to try to break through this situation. In addition, we observed the specific data of $C F$. The average value of judicial justice is 2.426 , and the variable distribution is inverted U-shaped. Nearly $90 \%$ of the enterprises have a relatively neutral attitude towards the current situation of judicial justice. Only a small number of enterprises consider the current judicial environment to be very unfair or very fair. Most enterprises in the market competition may not produce problems related to judicial justice, so there is no more extreme view. So, in the subjective evaluation of judicial justice, every enterprise's point of view is similar. In addition, they believe that the judicial justice or not has 
TABle 1: Variable design and description.

\begin{tabular}{|c|c|c|c|c|}
\hline Variable type & Variable name & $\begin{array}{l}\text { Variable definitions and } \\
\text { symbols }\end{array}$ & $\begin{array}{l}\text { The corresponding questions in the } \\
\text { questionnaire }\end{array}$ & Variable assignment \\
\hline $\begin{array}{l}\text { Dependent } \\
\text { variable }\end{array}$ & $\begin{array}{l}\text { Enterprise } \\
\text { innovation } \\
\text { behavior }\end{array}$ & $\begin{array}{c}\text { Innovation behavior R \& D } \\
\text { investment intensity (IBR) }\end{array}$ & $\begin{array}{l}\text { CNO.1 "in the last three years, has } \\
\text { this establishment introduced any } \\
\text { new products or services?" } \\
\text { CNO. } 4 \text { "in the last three years, did } \\
\text { this establishment spend on } \\
\text { research and development activities } \\
\text { within the establishment?" } \\
\text { D.2 "in fiscal year } 2011 \text {, what were } \\
\text { this establishment's total annual } \\
\text { sales for ALL products and } \\
\text { services?" } \\
\text { N.3 "in fiscal year 2009, three fiscal } \\
\text { years ago, what were total annual } \\
\text { sales for this establishment?" }\end{array}$ & Set to " $2 * \mathrm{CNo} 4 /(d 2 \mathrm{a}+n 3)$ " \\
\hline \multirow{3}{*}{$\begin{array}{l}\text { Independent } \\
\text { variable }\end{array}$} & \multirow[b]{2}{*}{$\begin{array}{l}\text { Competitive } \\
\text { order }\end{array}$} & $\begin{array}{l}\text { Whether the competitive } \\
\text { environment of enterprises } \\
\text { is orderly (C) }\end{array}$ & $\begin{array}{c}\text { E.11“does this establishment } \\
\text { compete against unregistered or } \\
\text { informal firms?” }\end{array}$ & "Yes" = $1 ; "$ No" = 0 \\
\hline & & $\begin{array}{l}\text { Degree of obstacles caused } \\
\text { by disorder of competitive } \\
\text { environment of enterprises } \\
\text { (CO) }\end{array}$ & $\begin{array}{l}\text { E. } 30 \text { "to what degree are practices of } \\
\text { copetitiors in the informal sector an } \\
\text { obstacle to the current operations of } \\
\text { this establishment?" }\end{array}$ & \multirow{2}{*}{$\begin{array}{l}\text { "No obstacle" }=1 \text {; "minor } \\
\text { obstacle" }=2 \text {; "moderate } \\
\text { obstacle" }=3 \text {; "major } \\
\text { obstacle" }=4 \text { '; "very severe } \\
\text { obstacle" }=5 \\
\text { "Strongly disagree" }=1 \text {; "tend to } \\
\text { disagree" }=2 \text {; "tend to agree" }=3 \text {; } \\
\text { "strongly agree" }=4\end{array}$} \\
\hline & $\begin{array}{l}\text { Impartiality } \\
\text { degree of court }\end{array}$ & $\begin{array}{l}\text { Impartiality degree of court } \\
\text { (CF) }\end{array}$ & $\begin{array}{l}\text { J.1 "the court system is fair, } \\
\text { impartial and uncorrupted" }\end{array}$ & \\
\hline \multirow{7}{*}{$\begin{array}{l}\text { Control } \\
\text { variable }\end{array}$} & \multirow{2}{*}{$\begin{array}{l}\text { Top manager } \\
\text { characteristics }\end{array}$} & $\begin{array}{l}\text { Top manager experience } \\
\text { (experience) }\end{array}$ & $\begin{array}{c}\text { B.7 "how many years of experience } \\
\text { working in this sector does the top } \\
\text { manager have?" }\end{array}$ & $\begin{array}{l}\text { Set to the original value of " } \\
\text { general manager service } \\
\text { experience" }\end{array}$ \\
\hline & & $\begin{array}{l}\text { Gender of top manager } \\
\text { (gender) }\end{array}$ & B.7a "is the top manager female?" & "Female" = 1; "male" = 0 \\
\hline & $\begin{array}{l}\text { International } \\
\text { certification }\end{array}$ & $\begin{array}{l}\text { Whether the enterprise have } \\
\text { international certification } \\
\text { (certification) }\end{array}$ & $\begin{array}{c}\text { B.8 "does this establishment have an } \\
\text { internationally recognized quality } \\
\text { certification?" }\end{array}$ & "Yes" = 1; "no" = 0 \\
\hline & \multirow{3}{*}{$\begin{array}{c}\text { Enterprise } \\
\text { characteristics }\end{array}$} & $\begin{array}{l}\text { Enterprise size, enterprise } \\
\text { staff size (size) }\end{array}$ & $\begin{array}{l}\text { L.1 "at the end of fiscal year } 2011 \text {, } \\
\text { how many permanent, full-time } \\
\text { individuals worked in this } \\
\text { establishment? Please include all } \\
\text { employees and managers" }\end{array}$ & $\begin{array}{l}\text { Set to the natural logarithm of the } \\
\text { number of employees }\end{array}$ \\
\hline & & $\begin{array}{l}\text { Enterprise age, the } \\
\text { operating time of the } \\
\text { enterprise (Age) }\end{array}$ & $\begin{array}{l}\text { B.5 "in what year did this } \\
\text { establishment begin operations?" }\end{array}$ & $\begin{array}{l}\text { Set to } 2018 \text { minus "year of business } \\
\text { start," plus } 1\end{array}$ \\
\hline & & $\begin{array}{l}\text { State-owned shares of the } \\
\text { enterprise, whether the } \\
\text { enterprise has state-owned } \\
\text { shares (SOE) }\end{array}$ & $\begin{array}{c}\text { B.2 "what percentage of this firm is } \\
\text { owned by each of the following? } \\
\text { Government of state" }\end{array}$ & $\begin{array}{c}\text { Set to: mark "yes" }=1 \text { if the answer } \\
\text { has a value; otherwise marked } \\
\text { "no" }=0\end{array}$ \\
\hline & $\begin{array}{c}\text { Regional } \\
\text { characteristics }\end{array}$ & $\begin{array}{l}\text { Characteristics of the } \\
\text { industry of enterprise } \\
\text { industry }\end{array}$ & A.2 "sampling region" & $\begin{array}{l}\text { Classified according to OECD } \\
\text { technology intensity standard. } \\
\text { There are four categories. Set to } \\
\text { three industry dummy variable } \\
\text { According to the Yangtze river } \\
\text { delta, Pan pearl river delta, Pan } \\
\text { bohai, and other four economic } \\
\text { circle classification. There are four } \\
\text { categories. Set to three zone } \\
\text { dummy variables }\end{array}$ \\
\hline
\end{tabular}

little impact on their innovation and other operational behavior and also will not have an impact on their judgment of the competitive environment. This view is supported by the answers to question $\mathrm{J}^{7} 0^{7}$ in the questionnaire. More than $90 \%$ of enterprises believe that the court has no obstacle to their operation. 
TABLE 2: Descriptive statistics and correlation analysis of main variables.

\begin{tabular}{|c|c|c|c|c|c|c|c|c|}
\hline Variable name & Obs & Mean value & Standard deviation & 1 & 2 & 3 & 4 & 5 \\
\hline 1.IBD & 1511 & 0.427 & 0.495 & - & & & & \\
\hline 2.IBR & 490 & 0.063 & 0.108 & $0.160^{* * *}$ & - & & & \\
\hline 3.C & 1440 & 0.487 & 0.500 & $-0.170^{* * *}$ & $-0.142^{* * *}$ & - & & \\
\hline 4.CO & 1492 & 0.507 & 0.461 & $0.112^{* * *}$ & $0.113^{* * *}$ & $-0.717^{* * *}$ & - & \\
\hline 5.CF & 1493 & 2.624 & 0.664 & 0.036 & -0.073 & $0.050^{*}$ & -0.033 & - \\
\hline
\end{tabular}

Note. ${ }^{* * *},{ }^{* *},{ }^{*}$, respectively, the coefficient is significant at the level of $1 \%, 5 \%, 10 \%$.

TABLE 3: Values of VIF.

\begin{tabular}{lll}
\hline Variable name & VIF & $1 /$ VIF \\
\hline C & 2.39 & 0.419 \\
CO & 2.43 & 0.412 \\
CF & 1.03 & 0.971 \\
Experience & 1.21 & 0.826 \\
Gender & 1.08 & 0.924 \\
Certification & 1.14 & 0.881 \\
Size & 1.22 & 0.820 \\
Age & 1.22 & 0.818 \\
SOE & 1.03 & 0.967 \\
Mean & 1.42 & \\
\hline
\end{tabular}

TABLe 4: Preliminary regression results of the models.

\begin{tabular}{|c|c|c|c|c|c|c|c|c|}
\hline \multirow{2}{*}{$\begin{array}{l}\text { Variable } \\
\text { name }\end{array}$} & \multicolumn{2}{|c|}{ Probit model } & \multicolumn{2}{|c|}{ Logit model } & \multicolumn{2}{|c|}{ OLS model } & \multicolumn{2}{|c|}{ Tobit model } \\
\hline & M1 & M2 & M3 & M4 & M5 & M6 & M7 & M8 \\
\hline $\mathrm{C}$ & $\begin{array}{c}-0.3766^{* * *} \\
(-5.31)\end{array}$ & $\begin{array}{c}-0.3706^{* * *} \\
(-3.34)\end{array}$ & $\begin{array}{c}-0.1239^{* * *} \\
(-3.46)\end{array}$ & $\begin{array}{c}-0.1268^{* * *} \\
(-3.54)\end{array}$ & $\begin{array}{c}-0.0247^{* * *} \\
(-3.08)\end{array}$ & $\begin{array}{c}-0.0228^{*} \\
(-1.85)\end{array}$ & $\begin{array}{c}-0.0366 \\
(-1.57)\end{array}$ & $\begin{array}{c}-0.0366 \\
(-1.60)\end{array}$ \\
\hline $\mathrm{CO}$ & - & $0.0008(0.08)$ & $\begin{array}{c}-0.0035 \\
(-0.10)\end{array}$ & $\begin{array}{l}-0.0031 \\
(-0.08)\end{array}$ & - & $0.0027(0.15)$ & $\begin{array}{l}-0.0119 \\
(-0.42)\end{array}$ & $\begin{array}{l}-0.0119 \\
(-0.43)\end{array}$ \\
\hline CF & - & - & $0.0101(0.51)$ & $0.0102(0.50)$ & - & - & $\begin{array}{c}-0.0089^{*} \\
(-1.89)\end{array}$ & $\begin{array}{c}-0.0089^{*} \\
(-1.92)\end{array}$ \\
\hline$C \times \mathrm{CF}$ & - & - & $\begin{array}{c}-0.0639 \\
(-1.04)\end{array}$ & $\begin{array}{c}-0.0620 \\
(-1.01)\end{array}$ & - & - & $0.0550(0.95)$ & $0.0550(0.97)$ \\
\hline $\mathrm{CO} \times \mathrm{CF}$ & - & - & $\begin{array}{c}-0.1097^{* *} \\
(-2.13)\end{array}$ & $\begin{array}{c}-0.1109^{* *} \\
(-1.91)\end{array}$ & - & 2014 & $0.0287(0.48)$ & $0.0287(0.49)$ \\
\hline Experience & $\begin{array}{c}0.0159^{* * * *} \\
(2.96)\end{array}$ & $\begin{array}{c}0.0156^{* * *} \\
(2.85)\end{array}$ & $\begin{array}{l}0.0050^{* * *} \\
(2.69)\end{array}$ & $\begin{array}{l}0.0050^{* * *} \\
(2.74)\end{array}$ & $\begin{array}{c}-0.0030^{* * * *} \\
(-4.41)\end{array}$ & $\begin{array}{c}-0.0030^{* * * *} \\
(-4.07)\end{array}$ & $\begin{array}{c}-0.0030^{* * * *} \\
(-3.83)\end{array}$ & $\begin{array}{c}-0.0030^{* * *} \\
(-3.90)\end{array}$ \\
\hline Gender & $\begin{array}{c}0.3420^{* *} \\
(2.33)\end{array}$ & $\begin{array}{c}0.3388^{* *} \\
(2.31)\end{array}$ & $\begin{array}{c}0.1102^{* *} \\
(2.23)\end{array}$ & $\begin{array}{c}0.1058^{* *} \\
(2.07)\end{array}$ & $0.0129(0.70)$ & $0.0127(0.67)$ & $0.0098(0.52)$ & $0.0098(0.53)$ \\
\hline Certification & $\begin{array}{c}0.2385^{* *} \\
(2.23)\end{array}$ & $\begin{array}{c}0.2369^{* *} \\
(2.19)\end{array}$ & $\begin{array}{c}0.0777^{* *} \\
(2.12)\end{array}$ & $\begin{array}{c}0.0803^{* *} \\
(2.18)\end{array}$ & $\begin{array}{c}0.0268^{* *} \\
(2.38)\end{array}$ & $\begin{array}{c}0.0268^{* *} \\
(2.36)\end{array}$ & $\begin{array}{c}0.0237^{* *} \\
(2.00)\end{array}$ & $\begin{array}{c}0.0237^{* *} \\
(2.04)\end{array}$ \\
\hline Size & $\begin{array}{c}0.1621^{* * *} \\
(4.98)\end{array}$ & $\begin{array}{c}0.1628^{* * *} \\
\quad(5.09)\end{array}$ & $\begin{array}{c}0.0546^{* * *} \\
5.21)\end{array}$ & $\begin{array}{l}0.0542^{* * *} \\
\quad(5.26)\end{array}$ & $\begin{array}{c}-0.0159^{* * *} \\
(-4.70)\end{array}$ & $\begin{array}{c}-0.0158^{* * *} \\
(-4.63)\end{array}$ & $\begin{array}{c}-0.0171^{* * *} \\
(-4.60)\end{array}$ & $\begin{array}{c}-0.0171^{* * *} \\
(-4.69)\end{array}$ \\
\hline Age & $\begin{array}{c}-0.0131^{* *} \\
(-2.18)\end{array}$ & $\begin{array}{c}-0.0131^{* *} \\
(-2.18)\end{array}$ & $\begin{array}{c}-0.0043^{* *} \\
(-2.14)\end{array}$ & $\begin{array}{c}-0.0043^{* *} \\
(-2.16)\end{array}$ & $\begin{array}{l}0.0019^{* * *} \\
(2.70)\end{array}$ & $\begin{array}{c}0.0019^{* * *} \\
(2.79)\end{array}$ & $\begin{array}{c}0.0020^{* * *} \\
(2.68)\end{array}$ & $\begin{array}{c}0.0020^{* * *} \\
(2.73)\end{array}$ \\
\hline SOE & $\begin{array}{c}-0.6908^{* * *} \\
(-3.07)\end{array}$ & $\begin{array}{c}-0.6948^{* * *} \\
(-3.09)\end{array}$ & $\begin{array}{c}-0.2240^{* * *} \\
(-2.96)\end{array}$ & $\begin{array}{c}-0.2228^{* * *} \\
(-2.76)\end{array}$ & $0.0002(0.01)$ & $0.0005(0.02)$ & $0.0072(0.25)$ & $0.0072(0.26)$ \\
\hline Indust & Control & Control & Control & Control & Control & Con & Control & Control \\
\hline Region & Control & Control & Control & Control & Control & Control & Control & Control \\
\hline Sample size & 1366 & 1362 & 1349 & 1349 & 456 & 456 & 452 & 397.31 \\
\hline
\end{tabular}

Note. (1) ${ }^{* * *},{ }^{* *},{ }^{*}$, respectively, the coefficient at the level of $1 \%, 5 \%, 10 \%$ significant. (2) The values in parentheses of model 1 to model 4 are the tested $z$ values, and those of model 5 to model 8 are the tested $t$ values.

Models 5-7 show that $C$ has reversed incentives for $I B R$, demonstrating that hypothesis $1 \mathrm{a}$ is a false proposition. After adding $C O$, the impact of $C$ on $I B R$ was weakened in model 6 , and the influence coefficient decreased from -0.0247 to -0.0228 . It shows that the competition order of enterprises also has a reverse effect on the R \& D input intensity of the enterprise. The bad competition order makes the company increase its own R \& D investment intensity. However, once this bad order becomes an obstacle to the operation of the company and the greater the degree of obstacles, the smaller 
the impact. In model 7 , the coefficient of $C$ is still positive, but it is not significant, and the coefficient of $C O$ also becomes negative. The coefficient of $C F$ is significantly negative, but the coefficients of the interaction terms of $C$ and $C F$ and $C O$ and $C F$ are both positive numbers. It shows that the lower the impartiality degree of the court is, the more the company will increase its R \& D investment intensity. Due to the existence of informal competitors, enterprises have received pressure from bad competition order. They try to get rid of such pressure or obstacles by increasing investment in innovation. At the same time, enterprises believe that the current level of judicial fairness is relatively low, and the possibility that such unfavorable competition order will become a barrier to business operations may increase. Then, the company's investment in innovation may be slightly reduced with the degree of obstacles. However, this cannot verify our hypothesis $2 b$. We have observed the cases of first instance of intellectual property rights handled by the China National Courts between 2009 and 2011. They accounted for 5 per thousand, 6 per thousand, and 8 per thousand of all kinds of cases handled by the national courts. This shows that the number of China's enterprises in the market competition involves intellectual property rights, unfair competition, and other issues and put into litigation procedures is little. That is to say, the real "deal" with the judicial system of enterprises is very few. These may lead to inconspicuous results of our research.

In consideration of the economic disparities between the eastern and western regions of China and the differences in the legal environment, in order to better validate the robustness of the model, we have divided the sample data according to the Chinese policy according to the eastern, central, and western regions. Due to the small sample in the central and western regions of the sample, we combined the western and central regions to form the midwestern regions. We have regressed on the sample division in Table 5. We find that the regression results in the eastern region are basically consistent with the original regression results, and the midwestern regions show very large differences. The reasons for this result may have the following reasons: first, there are differences in the number of samples. For the regression of IBD, there are 1080 samples in the eastern region and only 332 samples in the central and western regions. In the IBR study, the samples in the eastern region and the central and western regions were 269 and 120 samples, respectively. Second, the division between the eastern region and the central and western regions was originally divided by China according to policies, not all based on geographical location. The business environment in the central and western regions is quite different from that in the eastern region. However, the sample results in the eastern region once again supported our findings. At the same time, the regression of subsamples also shows that the impact of China's competition order on corporate innovation behavior is heterogeneous.

\section{Conclusions and Discussion}

Based on the data of China 2012 Enterprise Surveys Data set of World Bank enterprise survey, we empirically analyze the impact of orderly competition and judicial justice on enterprise innovation behavior. We found some conclusions as follows:

First, when there are unregistered or informal competitors in the market, enterprises will tend to choose innovation to improve the current situation of their own operations, and they may increase the R \& D investment. We are familiar with the "Shanzhai" phenomenon, which initially refers to those disorderly market competitors, such as small manufacturers and small workshops who do not have a license. It is difficult for them to enter the market through formal channels. They make some replication, imitation, and simple improvement on their products to quickly meet the demand of those who consume ability are limited. Some cost-effective products and services quickly introduced to the market to occupy it. Take Shanzhai mobile phones as an example. They used to be popular in three or four line cities in China. During the peak period of 2006-2007, there were more than 6000 Shangzhai mobile phone manufacturers in China, which gradually began to die out after 2011. Driven by the rapid development of local brand mobile phones and Shanzhai mobile phones, 5 of the top 10 IC design enterprises in 2010 were engaged in the development of network communication chips. These disorderly competitors did not hinder the development of China's mobile communication industry, but prompt more enterprises to seize the opportunity to constantly innovate. Some local brands such as Huawei, Oppo, and Vivo dug up different research innovations and rose rapidly and changed the situation that Shanzhai mobile phones only integrate functions, which brought the prosperity of China's mobile communication market.

Second, when the unregistered or informal competitors in the market become obstacles to the enterprise, with the rise of disorderly barriers to competition, enterprises began to reduce their innovation behavior decision-making or reduce the intensity of $\mathrm{R} \& \mathrm{D}$ investment. Once disorderly competition becomes an obstacle to enterprise operation, enterprise innovation behavior will not be able to get the benefits and innovation costs rise greatly. Furthermore, innovation achievement is difficult to be protected. Due to lack of confidence, enterprise innovation behavior will be suppressed, especially in the pharmaceutical manufacturing enterprises. In such industries with long innovation cycle, high innovation risk, and high innovation investment, most enterprises do not pay enough attention to or lack of confidence in major innovation, and disorderly competition will have a huge impact on enterprise income. Finally, R \& D investment will become a huge burden to the enterprises. The enterprises suddenly cannot maintain the original investment.

Third, the impartiality degree of court may have a moderating effect on the relationship between competition order and corporate innovation behavior. However, this regulatory effect has different effects on the choice of innovation behavior and the intensity of innovation input. In terms of innovation behavior choices, companies believe that the higher their level of impartiality in the judicial environment, the higher the level of protection for corporate 
TABLE 5: Regression results of enterprises in different regions.

\begin{tabular}{|c|c|c|c|c|}
\hline \multirow{2}{*}{ Variable name } & \multicolumn{2}{|c|}{ Eastern region } & \multicolumn{2}{|c|}{ Midwestern region } \\
\hline & IBD & IBR & IBD & IBR \\
\hline $\mathrm{C}$ & $-0.1646^{* * *}(-3.95)$ & $-0.0511(-1.54)$ & $0.1743(1.57)$ & $0.0061(0.28)$ \\
\hline $\mathrm{CO}$ & $-0.0288(-0.64)$ & $-0.0228(-0.65)$ & $0.1463(1.47)$ & $0.0317(0.87)$ \\
\hline $\mathrm{CF}$ & $0.0009(0.04)$ & $-0.0079(-1.51)$ & $0.0159(0.34)$ & $0.0118(1.30)$ \\
\hline$C \times C F$ & $-0.0441(-0.70)$ & $0.0585(0.84)$ & $-0.0943(-0.53)$ & $0.0105(0.26)$ \\
\hline $\mathrm{CO} \times \mathrm{CF}$ & $-0.0914^{*}(-1.66)$ & $0.0333(0.45)$ & $0.0280(0.15)$ & $0.0193(0.45)$ \\
\hline Experience & $0.0044^{* *}(2.03)$ & $-0.0038^{* * *}(-3.77)$ & $0.0136^{* *}(2.11)$ & $-0.0039(-1.45)$ \\
\hline Gender & $0.1174^{* *}(2.19)$ & $0.0094(0.42)$ & $0.0662(0.53)$ & $-0.0170(-0.77)$ \\
\hline Certification & $0.0503(1.36)$ & $0.0183(1.26)$ & $0.1632 * *(2.01)$ & $0.0287^{* *}(2.56)$ \\
\hline Size & $0.0574^{* * *}(5.47)$ & $-0.0168^{* * *}(-3.43)$ & $0.0585^{* *}(1.99)$ & $-0.0057(-1.22)$ \\
\hline Age & $-0.0024(-1.24)$ & $0.0024^{* *}(2.16)$ & $-0.0118^{* * *}(-2.82)$ & $0.0006(0.65)$ \\
\hline SOE & $-0.2236^{* *}(-2.55)$ & $-0.0094^{* * *}(-0.19)$ & $-0.2154(-1.30)$ & $-0.0355(-1.50)$ \\
\hline Industry & Control & Control & Control & Control \\
\hline Region & Control & Control & Control & Control \\
\hline Sample size & 1080 & 332 & 269 & 120 \\
\hline
\end{tabular}

Note. (1) ${ }^{* * *},{ }^{* *},{ }^{*}$, respectively, the coefficient at the level of $1 \%, 5 \%, 10 \%$ significant. (2) The values in parentheses of model 1 to model 4 are the tested $z$ values, and those of model 5 to model 8 are the tested $t$ values.

innovation outcomes. At this time, the higher the business obstacles caused by poor competition order, the more the companies will use innovation to improve the situation. With respect to the modest investment in innovation, enterprises believe that the level of judicial fairness is low and innovation has become a breakthrough in breaking through the barriers to poor competition. Therefore, they will continue to increase investment in innovation and create innovations with a higher level of technology to truly get rid of the influence of adverse competition order.

These conclusions are very consistent with China's market conditions. Although China's intellectual property protection is relatively weak, China's innovation has continued to develop rapidly in recent years. China is a "supereconomy" compared to other countries. For Chinese companies, most products have a huge market, and many markets are still not fully developed. Markets that can easily be entered by informal competitors often fall into the lower end of the market where products are of lower quality. Enterprises, through technology innovation, give up the original low-end market, enter, or open up the high-end market. This allows enterprises to develop rapidly.

Our research may have the following deficiencies: first, when we consider the dimension of orderly competition, we get the result that when there is disorderly competition in the market, and enterprises will tend to innovate. But, when this disorder becomes an obstacle, it starts to inhibit innovation. According to the abovementioned results, we speculate that there may be an inverted " $U$ " relationship between orderly competition and enterprise innovation behavior. But, limited by the data, this relationship is not fully proved in our research. We hope that, in the further research, we can find the appropriate variables to demonstrate our hypothesis. Secondly, under the influence of China's national conditions, there are fewer enterprises involved in judicial proceedings. In fact, most enterprises do not participate in and hold a more "neutral" attitude towards the issue of judicial justice. The subjective evaluation of judicial justice by enterprises as a measure is not enough to the point, which may make our hypothesis of regulatory role less obvious. We believe that it may be more effective to measure judicial justice in terms of enterprises' satisfaction with judicial services. In this way, we can avoid the uncertainty and neutrality in the evaluation of judicial justice. We hope we can find a more suitable way to deal with this problem in the future research.

\section{Data Availability}

The experimental data used to support the findings of this study may be released upon application to the World Bank, which can be contacted at https://microdata.worldbank.org/ index.php/catalog/1559.

\section{Conflicts of Interest}

The authors declare that there are no conflicts of interest regarding the publication of this paper.

\section{Acknowledgments}

This work was supported in part by the National Natural Science Foundation of China (71673145).

\section{References}

[1] G. M. Grossman and E. Helpman, "Quality ladders in the theory of growth," The Review of Economic Studies, vol. 58, no. 1, pp. 43-61, 1991.

[2] J. A. Schumpeter, Socialism, Capitalism and Democracy, Psychology Press, London, UK, 1942.

[3] J. P. Andrew, H. L. Sirkin, and J. Butman, Payback: Reaping the Rewards of innovation, Harvard Business Press, Cambridge, MA, USA, 2007.

[4] China's Entrepreneur Survey System, L. Bruton, and T. Zhang, "Under the new normal enterprise innovation: status quo, problems and counter measures-2015 China's entrepreneur growth and development survey report," Management World, no. 6, pp. 22-33, 2015, in Chinese. 
[5] A. Chongvilaivan, "Learning by exporting and high-tech capital deepening in Singapore manufacturing industries, 1974-2006," Applied Economics, vol. 44, no. 20, pp. 2551-2568, 2012.

[6] J. Hauknes and M. Knell, "Embodied knowledge and sectoral linkages: an input-output approach to the interaction of highand low-tech industries," Research Policy, vol. 38, no. 3, pp. 459-469, 2009.

[7] J.-P. Bonardi and R. Durand, "Managing network effects in high-tech markets," Academy of Management Perspectives, vol. 17, no. 4, pp. 40-52, 2003.

[8] K.-H. Tsai and J.-C. Wang, "R \& D productivity and the spillover effects of high-tech industry on the traditional manufacturing sector: the case of Taiwan," The World Economy, vol. 27, no. 10, pp. 1555-1570, 2004.

[9] P. M. Romer, "Endogenous technological change," Journal of political Economy, vol. 98, pp. 71-102, 1990.

[10] G. Cachon, P. Rard, P. H. Zipkin et al., "Complexity theory and organization science," Organization Science, vol. 10, pp. 216-232, 1999.

[11] D. R. Detienne and C.S. Koberg, "A fresh look at incremental and radical innovation in the entrepreneurial firm," Florida International University, Orlando, FL, USA, Dissertation, 2011.

[12] R. Crescenzi and L. Gagliardi, "The innovative performance of firms in heterogeneous environments: the interplay between external knowledge and internal absorptive capacities," Research Policy, vol. 47, no. 4, pp. 782-795, 2018.

[13] S. M. S. Krammer, R. Strange, and A. Lashitew, "The export performance of emerging economy firms: the influence of firm capabilities and institutional environments," International Business Review, vol. 27, no. 1, pp. 218-230, 2018.

[14] X. Shi and Y. Wu, "The effect of internal and external factors on innovative behaviour of Chinese manufacturing firms," China Economic Review, vol. 46, pp. S50-S64, 2017.

[15] M. Hermosilla and Y. Wu, "Market size and innovation: the intermediary role of technology licensing," Research Policy, vol. 47, no. 5, pp. 980-991, 2018.

[16] E. Thun, "Innovation at the middle of the pyramid: state policy, market segmentation, and the Chinese automotive sector," Technovation, vol. 70-71, pp. 7-19, 2018.

[17] J. Pfefer and G. Salancik, The External Control of Organizations, p. 109, Harper \& Row, Manhattan, NY, USA, 1978.

[18] M. M. Montoya-Weiss and R. Calantone, "Determinants of new product performance: a review and meta-analysis," Journal of Product Innovation Management, vol. 11, no. 5, pp. 397-417, 1994.

[19] R. Balachandra and J. H. Friar, "Factors for success in R\&D projects and new product innovation: a contextual framework," IEEE Transactions on Engineering Management, vol. 44, pp. 276-287, 2002.

[20] X. Fu, P. Mohnen, and G. Zanello, "Innovation and Productivity in Formal and Informal Firms in Ghana," Technological Forecasting and Social Change, vol. 131, pp. 315-325, 2018.

[21] P. C. Kostis, K. I. Kafka, and P. E. Petrakis, "Cultural change and innovation performance," Journal of Business Research, vol. 88, pp. 306-313, 2017.

[22] E. Cooper, "Craft development: socialist and capitalist," China Quarterly, vol. 83, pp. 447-460, 1980.

[23] N. Nuruzzaman, D. Singh, and C. Pattnaik, "Competing to be innovative: foreign competition and imitative innovation of emerging economy firms," International Business Review, vol. 28, no. 5, 2019.

[24] L. Hou, "When competition law meets telecom regulation: the Chinese context," Computer Law \& Security Review, vol. 31, no. 5, pp. 689-700, 2015.

[25] W. Liu and K. Atuahene-Gima, "Enhancing product innovation performance in a dysfunctional competitive environment: the roles of competitive strategies and market-based assets," Industrial Marketing Management, vol. 73, pp. 7-20, 2018.

[26] L. Wang, "Intellectual property protection in China," International Information \& Library Review, vol. 36, no. 3, pp. 253-261, 2004.

[27] K. B. Kahn, "Understanding innovation," Business Horizons, vol. 61 , no. 3, pp. 453-460, 2018.

[28] Z. Weiying, "Reputational foundation of the legal system," Economic Research Journal, vol. 1, pp. 3-13, 2002.

[29] K. J. Arrow, "Economic welfare and the allocation of resources for invention," in The Rate and Direction of Inventive Activity, pp. 609-626, National Bureau of Economic Research, Inc, Cambridge, MA, USA, 1962.

[30] R. A. Connolly and M. Hirschey, "R \& D, market structure, and profits: a value," Review of Economics \& Statistics, vol. 66, no. 4, pp. 682-686, 2001.

[31] M. E. Porter, The Competitive Advantage of Nations, Free Press, New York, NY, USA, 1990.

[32] M. Bai and G. Li, "Market competition and innovation: Schumpeter's hypothesis and its empirical verification," China Soft Science, no. 11, pp. 15-21, 2006, in Chinese.

[33] J. Zhang, W. Zheng, and F. Zhai, "How does competition affect innovation: evidence from China," China Industrial Economics, no. 11, pp. 56-68, 2014, in Chinese.

[34] R. He, H. Lin, and M. Wang, "Product market competition, executive incentives and corporate innovation-empirical evidence from listed Chinese companies," Finance \&Trade Economics, vol. 36, no. 2, pp. 125-135, 2015, in Chinese.

[35] I. Horowitz, "Firm size and research activity," Southern Economic Journal, vol. 28, no. 3, pp. 298-301, 1962.

[36] P. Aghion, C. Harris, P. Howitt, and J. Vickers, "Competition, imitation and growth with step-by-step innovation," Review of Economic Studies, vol. 68, no. 3, pp. 467-492, 2001.

[37] P. Vickers, N. Bloom, R. Blundell, R. Griffith, and P. Howitt, "Competition and innovation: an inverted-U relationship," The Quarterly Journal of Economics, vol. 120, no. 2, pp. 701$728,2005$.

[38] Q. Fan and M. han, "Our government R \& D input, market competition and independence innovation," Forum on Science and Technonlogy in China, no. 3, pp. 10-14, 2011, in Chinese.

[39] J. Li, H. Xue, and Z. Pan, "Product market competition of enterprise in manufacturing industry, organizational slack and enterprise technology innovation," China Economic Studies, no. 2, pp. 112-125, 2016, in Chinese.

[40] X. Xu, S. Zhang, and Q. Xu, "On the difference of innovation between stata-owned enterprises and private-owned enterprises under the market competition," Finance \& Trade Economics, vol. 38, no. 2, pp. 141-155, 2017, in Chinese.

[41] H. Li and J. Li, "Top management team conflict and entrepreneurial strategy making in China," Asia Pacific Journal of Management, vol. 26, no. 2, pp. 263-283, 2009.

[42] L. Cai, B. Chen, J. Chen, and G. D. Bruton, "Dysfunctional competition \& innovation strategy of new ventures as they mature," Journal of Business Research, vol. 78, pp. 111-118, 2017. 
[43] R.-J. B. Jean, R. R. Sinkovics, and T. P. Hiebaum, "The effects of supplier involvement and knowledge protection on product innovation in customer-supplier relationships: a study of global automotive suppliers in China," Journal of Product Innovation Management, vol. 31, no. 1, pp. 98-113, 2014.

[44] B. Jin and G. Li, "Enterprise innovation and enterprise competitiveness," Economics Information, no. 10, pp. 37-42, 2006, in Chinese.

[45] S. Cao and H. Chen, "Safeguarding judicial justice," People's Court, pp. 10-31, 2001, in Chinese.

[46] Z. Wang, "Evaluation of judicial justice," Law and Social Development, vol. 9, no. 4, pp. 72-85, 2003, in Chinese.

[47] Federal Trade Commission, To Promote Innovation: The Proper Balance of Competition and Patent Law and policy, Diane Publishing Co, Collingdale, PA, USA, 2003.

[48] G. Ghidini, Intellectual Property and Competition Law: The Innovation Nexus, Edward Elgar Publishing, Cheltenham, UK, 2006.

[49] A. S. Gutterman, Innovation and Competition Policy, Kluwer Law International, London, UK, 1997.

[50] B. B. Allred and W. G. Park, "The influence of patent protection on firm innovation investment in manufacturing industries," Journal of International Management, vol. 13, no. 2, pp. 91-109, 2007.

[51] K. Blind, J. Edler, and R. Nack, Micro- and Macro-Economic Implications of the Patentability of Software Innovations, Intellectual Property Rights in Information Technologies between Innovation and Competition, Fraunhofer Institute and Max Planck Institute, Munich, Germany, 2001.

[52] J. D. Angrist and J. S. Pischke, "Instrumental variables in action: sometimes you get what you need," Mostly Harmless Econometrics: An Empiricist's Companion, Princeton University Press, Princeton, NJ, USA, 2009.

[53] S. Sheng, K. Z. Zhou, and J. J. Li, "The effects of business and political ties on firm performance: evidence from China," Journal of Marketing, vol. 75, pp. 1-15, 2016.

[54] M. Hou, "How to evaluate judicial justice: from objective standard to subjective perception," Journal of Law Application, vol. 6, pp. 7-11, 2016, in Chinese.

[55] C. Jolls, C. R. Sunstein, and R. Thaler, "A behavioral approach to law and economics," Stanford Law Review, vol. 50, no. 5, pp. 1471-1550, 1998.

[56] T. R. Tyler and H. J. Smith, Social Justice and Social Movements Handbook of Social Psycology, McGraw-Hill, NewYork, NY, USA, 1995.

[57] D. C. Hambrick, "Upper echelons theory: an update," Academy of Management Review, vol. 32, pp. 334-343, 2007.

[58] X. Wang and M. Dass, "Building innovation capability: the role of top management innovativeness and relative-exploration orientation," Journal of Business Research, vol. 76, pp. 127-135, 2017.

[59] M. Terziovski and J.-L. Guerrero, "ISO 9000 quality system certification and its impact on product and process innovation performance," International Journal of Production Economics, vol. 158, pp. 197-207, 2014.

[60] J. Yi, J. Hong, and W. C. Hsu, "The role of state ownership and institutions in the innovation performance of emerging market enterprises: evidence from China," Technovation, vol. 62-63, pp. 4-13, 2017. 